\begin{abstract}
One of the technologies that are developing rapidly is $3 D$ printing. $3 D$ printing machines can create objects easily, quickly and in detail. There are three main steps that a $3 D$ printing machine goes through, namely design, printing and finishing. $3 D$ printers using polylactic acid are widely used in various types offields such as industrial machinery, spacecraft, consumer goods, electronic components, vehicles, medical industry, toy industry and others.

In this research, we succeeded in making an educational game tool called Tetris with the $3 D$ printing method using polylactic acid filaments. The process of consistently creating 3-dimensional objects from digital files by arranging many layers of thin metal in succession is called $3 D$ printing. Using additive manufacturing technology, 3D digital designs are turned into virtual products by sequentially depositing metals. $3 D$ printing provides reasonable feasibility to meet various parameters based on the engineering arena. By utilizing the advantages of PLA material, which has good tensile strength, good surface quality, is available in various colors and user-friendly, educational game tools are produced that have the advantage of being attractive, light, strong and easy to play. That way, making educational game tools using $3 D$ printing made from PLA can solve the problems with previous educational game tools, which are not easy to play and less attractive to early childhood. Educational games that have been made in this study can be used as a platform for learning children at the kindergarten to elementary school levels. The way to play this educational game Tetris is by attaching shapes to the main part of Tetris and matching them with other shapes, just like playing a puzzle where each shape that is installed must match the other shapes
\end{abstract}

Keywords: $3 D$ printing, educational game tools, polylactic acid
UDC37.014

DOI: $10.15587 / 1729-4061.2020 .216382$

\section{IMPLEMENTATION OF RAPID PROTOTYPING POLYLACTIC ACID USING 3D PRINTING TECHNOLOGY FOR EARLY EDUCATION APPLICATIONS}

Dwi Hadi Sulistyarini Master of Industrial Engineering*

E-mail: dwihadi@ub.ac.id

Debrina Puspita Andriani Master of Industrial Engineering* E-mail: debrina@ub.ac.id

Zefry Darmawan Doctor of Industrial Engineering*

E-mail: zefry_ti@ub.ac.id

Put u Hadi Setyarini

Doctor of Mechanichal Engineering Department of Mechanical Engineering**

E-mail: putu_hadi@ub.ac.id

*Department of Industrial Engineering**

**Brawijaya University

J. Mayjend Haryono, 167, Malang, Indonesia, 65145

Copyright (C) 2020, Dwi Hadi Sulistyarini,

Debrina Puspita Andriani, Zefry Darmawan, Putu Hadi Setyarini This is an open access article under the CC BY license (http://creativecommons.org/licenses/by/4.0) made to be a learning resource so that they gain learning experiences [4]. This experience will be useful for improving developmental aspects, such as physical/motoric, logical, emotional, social, language, cognitive and moral aspects [5]. Educational aids based on Science Technology Engineering Math (STEM) are anything that can be used as a means or a game tool that contains an educational value based on STEM and can develop all aspects of children's abilities, both from the surrounding environment and equipment that is deliberately made [6]. The difference between early education application and ordinary playing tools is that there are all kinds of means that can stimulate activities that make children happy, while educational play tools are play tools that can improve entertaining and educational functions. That is, educational play tools are a means that can stimulate children's activities to learn something without the child realizing it, either using modern technology or simple technology even traditional ones [7].

$3 \mathrm{D}$ printing with polylactic acid is a solution opportunity to solve the problem of lead time design process in educational game products. The long creative process starting from determining the design concept, making alternative design sketches, digital modeling, CAD [8], to making product 
prototypes will be greatly helped by the presence of a 3D printer [9]. Moreover, 3D printing is included in the rapid prototyping machine where in the process it does not waste unnecessary materials because the process does not cut the material but adds material components [10].

As a lecturer, we must be able to innovate to develop more attractive learning tools. One of them is by utilizing the latest technology with the need for educational facilities, especially for early childhood education. In this case study, we take advantage of the use of 3D printing technology to make learning tools in the form of educational games for early children in the form of Tetris games. The material used to produce Tetris is selected based on its usefulness, which can support the function of an educational game, namely polylactic acid.

\section{Literature review and problem statement}

The paper implementation of rapid prototyping polylactic acid using 3D printing technology for early education applications presents the results of research about the use of 3D printing with polylactic acid material as an educational game tool. It is shown that 3D printer has so many functions that can be used fully in our daily life, especially in educational. By implementation of rapid prototyping polylactic acid using 3D printing as an educational game tool, it can be one of the alternatives for teachers that can support teachers to carry out learning students. But there is a problem that has not been resolved regarding making this educational game product using 3D printing with PLA material. The reason for this is because there are still rare 3D printer machines available, the design time is not short, and limited funds. Ways to overcome these difficulties can be a topic of discussion in this paper that will discuss the use of PLA in 3D printing as an educational game tool, a method of design thinking in which this approach is used in the implementation of rapid prototyping polylactic acid using 3D printing technology for early education applications. However, for a deeper understanding of this paper, it is necessary to conduct a study on 3D printing, PLA material, design thinking, and educational game tools.

$3 \mathrm{D}$ printing or often referred to as additive manufacturing is the process of making a 3-dimensional solid object from a digital model. The $3 \mathrm{D}$ printing process is done with an additive process, where objects are created by placing/adding material layer by layer. Several types of materials can be used in 3D printing, but the most widely used are Acrylonitrile Butadiene Styrene (ABS) and Polylactic acid or Polylactide (PLA) [11]. Apart from their shape in the form of filaments, moreover, these two materials are most widely used in 3D printing because they are easy to obtain, cheap and more environmentally friendly. Both of these materials come from a thermoplastic group that has the property of being easily formed when heated and becomes solid again when cooled. The advantage of thermoplastic materials is that they can be recycled or reprocessed repeatedly so that they are more environmentally friendly [12]. Therefore, most existing 3D machines use ABS or PLA materials to make it easy to use.

ABS material is produced from fossil fuels and is not biodegradable. ABS consists of $15-35 \%$ acrylonitrile, 5-0 \% butadiene and $40-60 \%$ styrene [13]. So, the ABS material is stronger than pure polystyrene. Styrene gives a shiny plastic effect, while butadiene is a rubber substance that provides resistance even at low temperatures. $\mathrm{ABS}$ can be used in the temperature range of $-20^{\circ} \mathrm{C}$ to $80^{\circ} \mathrm{C}$ [14]. So, the ABS material is suitable for products and parts that are strong and heat resistant.

PLA material has many color choices, both solid and translucent and glossy, making it attractive to display. If the cooling is right this material is possible to print at a higher speed than ABS [15]. Therefore, this material is widely used for home printing, hobbies and in schools. This is also the reason why this research uses PLA materials.

Educational game tools are anything that can be used as a means or equipment for playing that contains an educational value and can stimulate children's brain growth to develop all aspects of children's abilities (potentials) [16]. There are many forms and kinds of educational game tools that are used as children's learning, such as puzzles, lego, and others. Meanwhile, according to Shofyatun, educational game tools are «a game tool specially designed for educational purposes, especially for preschool children in improving the developmental aspects of all children's potential» [17]. From these definitions, it can be concluded that educational game tools are equipment that can develop children's brain abilities. Some of the benefits of educational game tools are increasing children's creativity and development, training motor skills, training concentration, providing stimuli in the formation of behavior and developing basic abilities, and much more [18]. From the point of view of children's education, an educational game tool is needed and this educational game tool is what we call an educational game tool based on Science Technology Engineering Math (STEM). This educational game product can be facilitated by 3D printing using polylactic acid.

The concept of design thinking was proposed by Bryan Lawson in the book How Designers Think and later applied by Nigel Cross and Peter Rowe to general education and architecture. Design thinking is an iterative design process that includes three spaces (inspiration, idea and implementation) [19]. This emphasizes that designers must use intuitive thinking patterns in expressing problems through observation and empathy. At the same time, they must also consider the needs and behavior of users, the technological feasibility and the market sustainability of the product or service. This study integrates design thinking initiatives and creativity tools to develop a design thinking-based product design process.

\section{The aim and objectives of the study}

The aim of the study is to conduct rapid prototyping of polylactic acid using 3D printing technology to produce an early educational application. This educational application will be made based on STEM for early childhood education in Malang City. To achieve the set aim, the following objectives are accomplished:

- design the educational game tools using the design thinking method;

- study the use of polylactic acid in rapid prototyping;

- produce educational play tools using 3D printing.

\section{Methods of research}

There are 4 stages in this research. The first is literature \& field studies, which is carried out by observing several early childhood educational institutions in Malang City to find out the real conditions that exist in early childhood education related to educational play tools. The second is 
problem identification, which is carried out by surveying several school principals, teachers and students who are involved in educational games.

Furthermore, namely the determination of research objectives is intended so that research can focus on the problem to be studied, so that research can be carried out systematically and not deviating from the problem under study. In addition, the research objective is intended to measure the success of the research conducted by the researcher. The last one is the formulation \& design of educational game tools, which is carried out to get product concepts that will be applied related to educational game tools.

\section{Research results}

In this study, the design thinking method is used in determining the design of educational game tools. Here is a step in design thinking [19].

\section{1. Understand}

In the first phase of data collection and information about the understanding of educational game tools, what are the benefits for us and how it is used in daily life. The benefits are to assist users in improving the developmental aspects of all children's potential such as helping in training motor skills, training concentration, training language and insights to introduce colors and shapes in early childhood. The educational game tools use the majority of wood base materials. Wood has some advantages that are more durable but also has some disadvantages that are too heavy when compared to plastic materials and have a less varied shape because the manufacturing process is still relatively traditional so the resulting form is limited.

\section{2. Observe}

The next step is to understand the needs of customers who can help in defining design issues. 3D printing can be used in educational game tools, which can improve child development. Its light, safe and strong characteristics are a consideration for consumers in choosing educational game tools.

To understand the needs of customers, we have to distribute the questionnaire to several kindergarten teachers and principals. Here are the conclusions that can be drawn from distributing 50 questionnaires (Table 1).

The material chosen for use in the production of this educational game tool is PLA material. PLA is a thermoplastic aliphatic polyester derived from renewable resources, such as corn starch (in the United States), tapioca roots, chips or starch (mostly in Asia), or sugarcane (in the rest of the world) commonly used in the food industry so it is safe for children if the toy gets into the child's mouth as long as it is not swallowed, and has the advantages compared to plastics made from petroleum:

1) biodegradable, meaning that PLA can be broken down naturally in the environment by microorganisms;

2) biocompatible, where under normal conditions, this type of plastic can be accepted by biological cells or tissues;

3) produced from changeable materials (including industrial waste) and not from petroleum;

4) $100 \%$ recyclable, via hydrolysis, lactic acid can be obtained and reused for different applications or can be combined to produce other products;

5) does not use organic/toxic solvents in producing PLA;

6) can be completely burned and produce $\mathrm{CO}_{2}$ gas and air.
Table 1

\section{Questionnaire results}

\begin{tabular}{|c|c|}
\hline Question & Answer \\
\hline \multirow{3}{*}{$\begin{array}{l}\text { 1. Difficulties } \\
\text { experienced } \\
\text { when using } \\
\text { educational } \\
\text { game tools }\end{array}$} & $\begin{array}{l}\text { There is a part of the educational game tools, which } \\
\text { is detached }\end{array}$ \\
\hline & Less varied types of educational game tools \\
\hline & Unfavorable reactions in children \\
\hline \multirow{8}{*}{$\begin{array}{l}2 . \text { Things } \\
\text { to consider } \\
\text { in choosing } \\
\text { educational } \\
\text { game tools }\end{array}$} & Props that are easy for children to understand \\
\hline & The material is strong \\
\hline & Able to foster children's creativity \\
\hline & Safety for children \\
\hline & Helping children learn to think \\
\hline & Easy for children to learn \\
\hline & $\begin{array}{l}\text { Has many color variations so that children are not } \\
\text { bored }\end{array}$ \\
\hline & The shape is attractive \\
\hline \multirow{8}{*}{$\begin{array}{l}\text { 3. Benefits of } \\
\text { educational } \\
\text { game tools } \\
\text { recently used }\end{array}$} & Attractive colors for children \\
\hline & The shape is attractive \\
\hline & Light \\
\hline & Easy to understand and easy for kids to use \\
\hline & $\begin{array}{l}\text { Can train motor skills and improve aspects of child- } \\
\text { hood development }\end{array}$ \\
\hline & Improve children's creativity \\
\hline & $\begin{array}{l}\text { Encourage children's interest and motivation to } \\
\text { learn because it is fun }\end{array}$ \\
\hline & Easy to get anywhere \\
\hline \multirow{4}{*}{$\begin{array}{l}\text { 4. Drawbacks } \\
\text { of educational } \\
\text { game tools } \\
\text { recently used }\end{array}$} & $\begin{array}{l}\text { Material made of wood, which can be dangerous for } \\
\text { children if thrown }\end{array}$ \\
\hline & $\begin{array}{l}\text { Requires well-prepared learning strategies and media. } \\
\text { If not prepared, the learning objectives cannot be } \\
\text { achieved }\end{array}$ \\
\hline & $\begin{array}{l}\text { The learning we do must be properly prepared so } \\
\text { that the learning we carry out reaches the goal }\end{array}$ \\
\hline & Not durable or easily damaged \\
\hline \multirow{10}{*}{$\begin{array}{l}\text { 5. Expected } \\
\text { educational } \\
\text { game tools } \\
\text { characteristics }\end{array}$} & $\begin{array}{l}\text { APE which can enhance and encourage children's } \\
\text { creativity }\end{array}$ \\
\hline & Contains educational value \\
\hline & Safe for children \\
\hline & Easy to use \\
\hline & Not easily damaged (durable) \\
\hline & Serves to develop children's abilities \\
\hline & Games according to the child's age development \\
\hline & Games that make children more active \\
\hline & Improve children's motor skills \\
\hline & $\begin{array}{l}\text { Educational game tools able to foster creativity, easy } \\
\text { to obtain, have unlimited creative development }\end{array}$ \\
\hline
\end{tabular}

\section{3. Point of view}

The third step is to integrate and analyze data from the previous two steps. Consumer needs and design issues are obtained as follows:

a) consumer needs:

- educational game tools that can improve aspects of child development (motor skills, creativity, etc.) with safe materials; 
- easy to use and durable;

- can unload;

Morphological chart

b) design problem:

- how can educational game tools improve aspects of early childhood development?

- there is no educational game tool that uses rapid prototyping polylactic acid with 3D printing on the market;

- how is the strength and security of the use of rapid prototyping polylactic acid with $3 \mathrm{D}$ printing on educational game tools?

\begin{tabular}{|l|c|c|c|c|}
\hline \multirow{2}{*}{ Function criteria } & Criteria & \multicolumn{3}{|c|}{ Design selection } \\
\hline \multirow{4}{*}{$\begin{array}{l}\text { Provides Motor } \\
\text { Functions }\end{array}$} & Tetris Height $(A)$ & $10 \mathrm{~cm}(A 1)$ & $17 \mathrm{~cm}(A 2)$ & $30 \mathrm{~cm}(A 3)$ \\
\cline { 2 - 5 } & Hook Shape $(B)$ & Circle $(B 1)$ & Square $(B 2)$ & - \\
\cline { 2 - 5 } & Hook Lenght $(C)$ & $0.5 \mathrm{~cm}(C 1)$ & $1 \mathrm{~cm}(C 2)$ & $1.5 \mathrm{~cm}(C 3)$ \\
\cline { 2 - 5 } & Width of Shape $(D)$ & $1.5 \mathrm{~cm}(D 1)$ & $2 \mathrm{~cm}(D 2)$ & $3 \mathrm{~cm}(D 3)$ \\
\hline \multirow{2}{*}{$\begin{array}{l}\text { Provides Sensory } \\
\text { Functions }\end{array}$} & Color Combination $(E)$ & 6 Colors $(E 1)$ & 1 Color $(E 2)$ & 3 Colors $(E 3)$ \\
\cline { 2 - 5 } & Surfaces $(F)$ & Smooth $(F 1)$ & Serrated $(F 2)$ & - \\
\hline $\begin{array}{l}\text { Provides Cogni- } \\
\text { tive Functions }\end{array}$ & $\begin{array}{c}\text { Train children to do } \\
\text { a combination of shapes }(G)\end{array}$ & $\begin{array}{c}\text { Combinations of } \\
6 \text { Shapes }(G 1)\end{array}$ & $\begin{array}{c}\text { Combinations of } \\
12 \text { Shapes }(G 2)\end{array}$ & - \\
\hline
\end{tabular}

\section{4. Ideate}

a) Brainstorming and classification.

Classify educational game tools based on functions or roles. Based on functions and roles, educational game tools can be classified into 3, namely sensory, motor and cognitive. Sensory is the ability of a child to use the senses in his body, motor skills are the ability to move a child possesses, and cognitive is the core skill required to perform any task from the simplest to the most complex.

b) Morphological chart.

The next step is to determine the criteria and design options of Tetris using a morphological chart. The morphological chart is shown in Table 2.

c) Alternative Concepts.

Concept I: A1-B2-C1-D3-E1-F1-G2.

In Concept I, the Tetris has function criteria to provide motor functions with a Tetris height of $10 \mathrm{~cm}$, with a square hook shape, the hook has a length of $0.5 \mathrm{~cm}$, and a shape width of $3 \mathrm{~cm}$. Provides a sensory function with a color combination in the form of 6 color combinations, and with a smooth surface. Provides a cognitive function with a combination of shapes as many as 12 combinations of shapes.

Concept II: A2-B1-C1-D2-E2-F2-G2.

In Concept II, the Tetris has function criteria to provide motor functions with a Tetris height of $17 \mathrm{~cm}$, with a circular hook shape, the hook has a length of $0.5 \mathrm{~cm}$, and a shape width of $2 \mathrm{~cm}$. Provides a sensory function with a color combination in the form of 1 color combination, and with a jagged surface. Provides a cognitive function with a combination of shapes as many as 12 shape combinations.

Concept III: A3-B2-C3-D1-E3-F2-G1.

In Concept III, the Tetris has function criteria to provide motor functions with a Tetris height of $30 \mathrm{~cm}$, with a square hook shape, the hook has a length of $1.5 \mathrm{~cm}$, and a shape width of $1.5 \mathrm{~cm}$. Provides a sensory function with color combinations in the form of 3 color combinations, and with a jagged surface. Provides a cognitive function with 6 combinations of shapes.

Concept IV: A2-B1-C2-D3-E2-F1-G1.

In Concept IV, the Tetris has function criteria to provide motor functions with a Tetris height of $17 \mathrm{~cm}$, with a circular hook shape, the hook has a length of $1 \mathrm{~cm}$, and a shape width of $3 \mathrm{~cm}$. Provides a sensory function with a combination of colors in the form of 1 color combination, and with a smooth surface. Provides a cognitive function with 6 combinations of shapes.
Concept V: A2-B2-C2-D1-E3-F1-G1.

In the concept of $\mathrm{V}$, the Tetris has function criteria to provide motor functions with a Tetris height of $17 \mathrm{~cm}$, with a square hook shape, the hook has a length of $1 \mathrm{~cm}$, and a shape width of $1.5 \mathrm{~cm}$. Provides a sensory function with a color combination in the form of 3 color combinations, and with a smooth surface. Provides a cognitive function with 6 combinations of shapes.

After making the alternative concepts, the next step is making the PUGH Matrix for eleminating copcepts and choosing the most suitable concept by comparing with the existing educational game tools, which is a puzzle. The PUGH Matrix is shown in Table 3.

Table 3

PUGH Matrix

\begin{tabular}{|c|c|c|c|c|c|c|}
\hline \multirow{2}{*}{ Function Criteria } & \multicolumn{7}{|c|}{ Concept } \\
\cline { 2 - 7 } & I & II & III & IV & V & Puzzle \\
\hline Main Motor & 0 & 0 & + & + & + & 0 \\
\hline Main Sensory & + & - & - & 0 & + & 0 \\
\hline Main Cognitive & + & + & + & + & + & 0 \\
\hline Sum of + & 2 & 1 & 2 & 2 & 3 & \\
\hline Sum of 0 & 1 & 1 & 0 & 1 & 0 & \\
\hline Sum of - & 0 & 1 & 1 & 0 & 0 & \\
\hline Final Score & 2 & 0 & 1 & 2 & 3 & \\
\hline Ranking & 3 & 5 & 4 & 2 & 1 & \\
\hline Continuation & No & No & No & No & Yes & \\
\hline
\end{tabular}

The designs of the selected concept (Concept V) are shown in Fig. 1-3. The designs of the main components of Tetris are shown in Fig. 1.

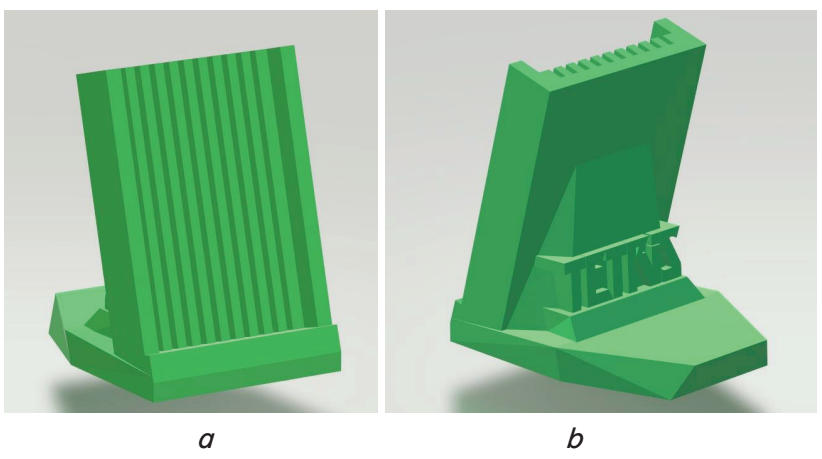

Fig. 1. Design of the selected concept: $a-$ the front of the Tetris; $b-$ the back of the Tetris 
The designs of $\mathrm{S}$ shape, $\mathrm{T}$ shape and $\mathrm{O}$ shape are shown in Fig. 2.

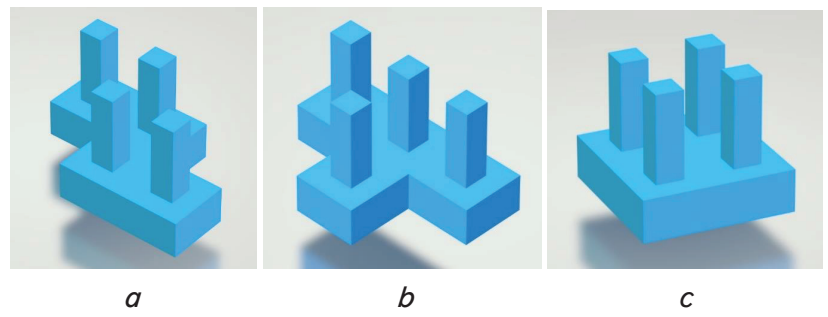

Fig. 2. Design of the selected concept: $a-\mathrm{S}$ shape; $b-\mathrm{T}$ shape; $c-\mathrm{O}$ shape

The designs of $\mathrm{Z}$ shape, $\mathrm{J}$ shape and I shape are shown in Fig. 3.

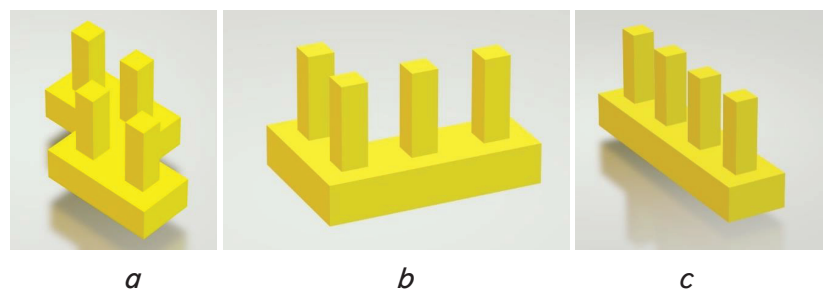

Fig. 3. Design of the selected concept: $a$ - O shape; $b$ - J shape; $c$ - I shape

\section{d) AEIOU and $5 \mathrm{~W} 1 \mathrm{H}$.}

Based on the optimal concept selected using the PUGH Matrix in Step 4.3, the usage environment, components, functions, mechanisms, and target customers of the design concept are then defined using AEIOU (activity, environment, interface, object, user) and 5W1H (what, where, when, why, who and how), which helps users determine target customers and service products.

This method is useful for researchers in preparing the scope of work to be carried out. The following is Table 4 of the relationship between the AEIOU method parameters and the research target.

Table 4

Relationship between AEIOU method parameters and research target

\begin{tabular}{|c|l|l|}
\hline No. & Parameter & \multicolumn{1}{|c|}{ Research target } \\
\hline 1 & Activities & $\begin{array}{l}\text { Aims to direct what specific activities are car- } \\
\text { ried out in a learning process and are associated } \\
\text { with play activities }\end{array}$ \\
\hline 2 & $\begin{array}{l}\text { Environ- } \\
\text { ment }\end{array}$ & $\begin{array}{l}\text { Directing the determination of the place with } \\
\text { what kind of environment is needed in a learn- } \\
\text { ing activity with educational play tools }\end{array}$ \\
\hline 3 & $\begin{array}{l}\text { Interac- } \\
\text { tion }\end{array}$ & $\begin{array}{l}\text { Determine what will happen in the interaction } \\
\text { between people or people with an object. The in- } \\
\text { teraction researched and directed is the interac- } \\
\text { tion of early childhood in games in the learning } \\
\text { process }\end{array}$ \\
\hline 5 & Objects & $\begin{array}{l}\text { Relates to directing what objects are needed in } \\
\text { an environment and how these objects interact } \\
\text { with activities. In this case, the object is direc- } \\
\text { ted at the toy object and the system applied }\end{array}$ \\
\hline & $\begin{array}{l}\text { User is the person who will be observed, either } \\
\text { role, relationship or assessment. These users are } \\
\text { early childhood }\end{array}$ \\
\hline
\end{tabular}

The $5 \mathrm{~W}+1 \mathrm{H}$ obtained in the design of educational game tools for child development activities are as follows (Table 5).

$5 \mathrm{~W}+1 \mathrm{H}$

Table 5

\begin{tabular}{|c|c|l|}
\hline No. & $5 \mathrm{~W}+1 \mathrm{H}$ & \multicolumn{1}{|c|}{ Explanation } \\
\hline 1 & What & $\begin{array}{l}\text { In this case study, the design that will be carried } \\
\text { out is the design of means of optimizing the system } \\
\text { for playing sensory, playing motor, playing roles or } \\
\text { playing symbolic and playing development for the } \\
\text { development of children's activities at an early age }\end{array}$ \\
\hline 2 & Where & $\begin{array}{l}\text { This educational toy is used in the classroom, which } \\
\text { in its operation will be attended by PAUD teachers }\end{array}$ \\
\hline 3 & When & When children do play activities in the classroom \\
\hline 4 & Why & $\begin{array}{l}\text { Because it is necessary to develop a design of } \\
\text { a child's toy, especially in the introduction of geo- } \\
\text { metric shapes, numbers, sounds and colors that can } \\
\text { be understood well }\end{array}$ \\
\hline 5 & Who & $\begin{array}{l}\text { The target market is the design of this geometric } \\
\text { shape, number and color recognition product for } \\
\text { early childhood }\end{array}$ \\
\hline 6 & How & $\begin{array}{l}\text { An overview of the design of means of introduc- } \\
\text { ing educational game tools for child development } \\
\text { activities is in the form of educational toys, which } \\
\text { can train the development of sensory play, motor } \\
\text { play, role play or symbolic play and play develop- } \\
\text { ment in the introduction of geometric shapes, num- } \\
\text { bers, sounds and colors in daily learning activities } \\
\text { while playing }\end{array}$ \\
\hline
\end{tabular}

e) Scenario Building and Storytelling.

This section involves the persona of the target customer obtained in Step 4.4, and provides a brief and specific description of the target customer's basic characteristics (name, gender, occupation, education, hobbies, and personality). With whom, where, what and when to focus, a written script procedural framework, and a brief description of the problems customers might face in certain situations when they use the product.

The target customers of this product are kindergarten until elementary school children aged $4-8$ years, male and female. This product will be used as a learning medium that aims to improve sensory abilities, improve motor skills, introduce roles and teach symbols, and increase creativity. In the operation, the children will be accompanied by kindergarten teachers, this product will be used in the classroom and it is hoped that it will improve the children's motor, sensory and intelligence abilities.

This product will be made using a $3 \mathrm{D}$ printer and will be done with an additive process [20], for the materials used in making the product, namely Acrylonitrile Butadiene Styrene (ABS) and Polylactic acid or Polylactide (PLA) [21]. Work on the product will be carried out in stages for each part and will be put together on the board so that later the product, which consists of several toys, can be neatly packed on the board.

Problems that will be faced when using the product can also be minimized due to the use of a $3 \mathrm{D}$ printer. When there is damage to one of the parts, the part can be reprinted and repaired [22]. Environmentally friendly materials are also a positive point because when the product is not used it can be recycled and reprocessed without producing waste that can disturb the environment [23].

After determining the selected concept and making a concept design, then a prototype is made using $3 \mathrm{D}$ printing 
in accordance with the selected concept design that has been made [24]. The purpose of making a prototype is to assist the design team in rechecking whether the design meets the needs and whether revisions or repairs need to be made [25].

Following the compilation of the information from the various stages and design concept optimization, a model was constructed, which helped the design team in re-examining whether the design met their needs and whether any revisions or improvements were necessary. The final concept designs produced by this case study are shown in Fig. 4, 5. The $3 \mathrm{D}$ print results of the main components are shown in Fig. 4.

The 3D print results of Tetris shapes are shown in Fig. 5.

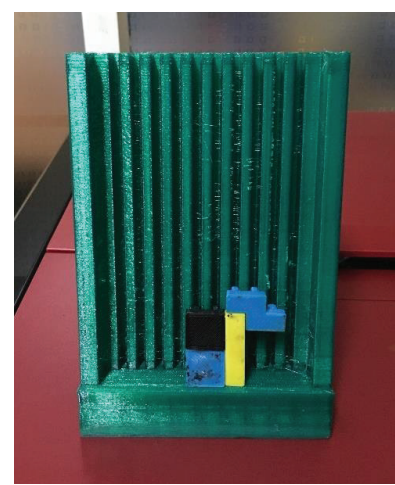

$a$

Fig. 4. 3D print results:

$a$ - the front of the Tetris; $b-$ the back of the Tetris

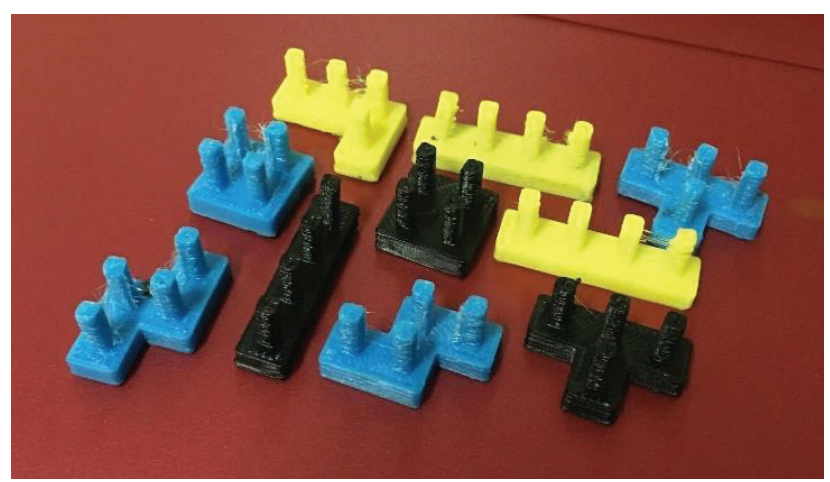

Fig. 5. 3D print result shapes

After the prototype is made, the next step, also the last, is the test. The use of this last step is to test whether the design and function of the product that has been made are in accordance with the designs that have been made previously.

This step helps ascertain whether the design concept meets technological constraints, market needs, and the needs of target users. At the test stage, a prototype test is carried out directly to the user. At this stage, you can see how users interact with the prototype and collect feedback in the form of their experiences of using the prototype [26].

\section{Discussion of experimental results}

In this study, an educational game tool product was made using a Da Vinci 1.0 Pro 3In1 3D Printer machine with PLAbased materials. The educational game tool made is Tetris. The following is a picture of the Tetris educational game that has been made (Fig. 6).

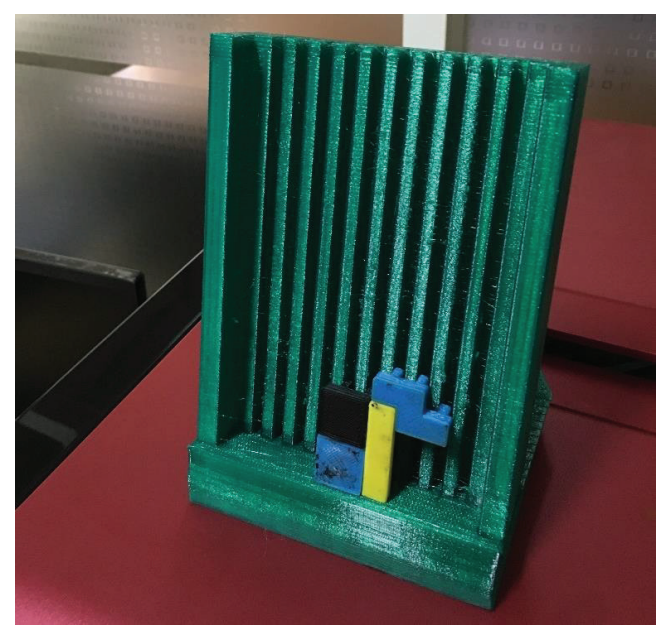

Fig. 6. Educational game tool Tetris

From these results, it can be seen that the educational game tool is in accordance with the design that has been made and has a function as an educational game tool. These results also show that it has interesting color variations and a smooth surface. Another result that cannot be seen with only pictures is that this Tetris product is light and strong so it is not easily damaged when played and is very suitable for children's learning media.

However, there are some problems from the results made, namely the separation distance on the main part of the Tetris is too narrow, making it difficult to attach the shape to it.

The solution to this problem is to redesign it by increasing the size of the separation distance on the main part of Tetris so the shape can be easier to attach.

The advantage of this research is that it offers a new alternative in making educational game tools for early childhood, which has many advantages including more attractive, lighter, easy to use and strong.

The limitation of this research is that there is only one machine used in the manufacture of products, namely the Da Vinci 1.0 Pro 3In1 3D printer machine, only one material is used, namely PLA, only one product is produced and the use of colors is limited, namely 4 colors consisting of green, black, blue and yellow.

The weakness in this study lies in the lack of research on the strength of the PLA material used against the prototype results that have been made using a $3 \mathrm{D}$ printer.

The development of this research is the use of PLA material in 3D printing as an educational game tool that can be used properly as a learning method for children. The difficulty faced by this study is in determining the design that must be in accordance with the needs of consumers who must also consider the limitations that exist in PLA machines and materials.

\section{Conclusions}

1. In design thinking there are 4 steps including understand, observe, point of view and ideate. Based on the morphological chart that has been adjusted to the expected function criteria and criteria, of the 5 existing concepts, concept $\mathrm{V}$ with a final value of 3 is chosen.

2. PLA material has many color choices, both solid and translucent and glossy, making it attractive to display. 
So PLA is the most suitable material for educational game tools.

3. Material used in the manufacture of products is polylactic acid (PLA) with 4 different colors that are green, blue, black and yellow.

\section{Acknowledgments}

We would like to acknowledge to the Manufacturing Systems Laboratory who played a role in the implementation of this research.

\section{References}

1. Ligon, S. C., Liska, R., Stampfl, J., Gurr, M., Mülhaupt, R. (2017). Polymers for 3D Printing and Customized Additive Manufacturing. Chemical Reviews, 117 (15), 10212-10290. doi: https://doi.org/10.1021/acs.chemrev.7b00074

2. Shahi, S., Baljinder (2016). Advanced Manufacturing Teknik (Printing 3D). Master's of Technology CAD/CAM Department of Mechanical Engineering, BBSBEC Fatehgarh Sahib, 4.

3. Muazzomi, N. (2017). Pengembangan Alat Permainan Edukatif Pendidikan Anak Usia Dini Melalui Aplikasi Microsoft Powerpoint. Jurnal Ilmiah Universitas Batanghari Jambi, 17 (1), 133-142.

4. Cooper, K. (2001). Rapid Prototyping Technology. CRC Press, 248. doi: https://doi.org/10.1201/9780203910795

5. Aisyah, S. (2008). Perkembangan dan konsep dasar pengembangan anak usia dini. Jakarta: Universitas Terbuka.

6. Hasnida (2015). Media Pembelajaran Kreatif Mendukung Pembelajaran Pada Anak Usia Dini. Jakarta: PT Luxima Metro Media, 186.

7. Vitianingsih, A. V. (2016). Game Edukasi sebagai Media Pembelajaran Pendidikan Anak Usia Dini. Jurnal INFORM, 1 (1).

8. Sloten, V. (2000). Computer Aided Design of Prostheses. Industrial Ceramics, 20 (2), 109-111.

9. Kamran, M., Saxena, A. (2016). A Comprehensive Study on 3D Printing Technology. MIT International Journal of Mechanical Engineering, 6 (2), 63-69.

10. Widyanto, S. (2012). Pengembangan teknologi rapid prototyping untuk pembuatan produk-produk multi material. J@ti Undip: Jurnal Teknik Industri, 3 (1), 10-16.

11. Johansson-Sköldberg, U., Woodilla, J., Çetinkaya, M. (2013). Design Thinking: Past, Present and Possible Futures. Creativity and Innovation Management, 22 (2), 121-146. doi: https://doi.org/10.1111/caim.12023

12. Jurrens, K. K. (1999). Standards for the rapid prototyping industry. Rapid Prototyping Journal, 5 (4), 169-178. doi: https:// doi.org/10.1108/13552549910295514

13. Lubis, S., Djamil, S., Yolanda, Y. (2016). Pengaruh orientasi objek pada proses 3d printing bahan polymer pla dan abs terhadap kekuatan tarik dan ketelitian dimensi produk. SINERGI, 20 (1), 27. doi: https://doi.org/10.22441/sinergi.2016.1.005

14. Rolina, N. (2012). Alat Permainan edukatif Anak Usia Dini. Yogyakarta: Penerbit Ombak.

15. Alsoufi, M. S., Elsayed, A. E. (2017). How Surface Roughness Performance of Printed Parts Manufactured by Desktop FDM 3D Printer with PLA+ is influenced by Measuring Direction. American Journal of Mechanical Engineering, 5 (5), 211-222.

16. Balasubramanian, T., Saminathan, B. (2015). Use of Multimedia - As A Tool for Effective Learning. International Journal of Scientific Research, 4 (12), 18-19.

17. Arif, M. N., Sumbawati, M. S. (2016). Pengembangan Game Edukasi Interaktif pada Mata Pelajaran Komposisi Foto Digital Kelas XI di SMK Negeri 1 Surabaya. Jurnal IT-EDU, 1 (2), 28-36.

18. Khobir, A. (2009). Upaya Mendidik Anak Melalui Permainan Edukatif. Forum Tarbiyah, 7 (2), 195-208.

19. Brown, T., Wyatt, J. (2010). Design Thinking for Social Innovation. Development Outreach, 12 (1), 29-43. doi: https:// doi.org/10.1596/1020-797x_12_1_29

20. Excell, J. (2013). The rise of additive manufacturing. The Engineer.

21. Serra, T., Planell, J. A., Navarro, M. (2013). High-resolution PLA-based composite scaffolds via 3-D printing technology. Acta Biomaterialia, 9 (3), 5521-5530. doi: https://doi.org/10.1016/j.actbio.2012.10.041

22. Taufik, M., Jain, P. K. (2013). Role of build orientation in layered manufacturing: a review. International Journal of Manufacturing Technology and Management, 27 (1/2/3), 47. doi https://doi.org/10.1504/ijmtm.2013.058637

23. Zulkifli, A. (2007). Rapid Prototyping Teknologi: Aplikasi pada Bidang Medis. Jurnal TeknikA, 27 (3), $78-83$.

24. Yan, L., Han, X. (2016). 3-Dimensional Printing Rapid Prototyping for Intracranial Aneurysm Coiling: A Good Example of Precise Medicine. World Neurosurgery, 86, 8. doi: https://doi.org/10.1016/j.wneu.2015.06.051

25. Chua, C. K., Leong, K. F., Lin, C. S. (2003). Rapid Prototyping. Principles and Applications. World Scientific Publishing Co Pte Ltd, 448. doi: https://doi.org/10.1142/5064

26. Jacobs, P. F. (1992). Rapid Prototyping \& Manufacturing: Fundamentals of Stereolithography. Society of Manufacturing Engineers, 434. 